\title{
HOW EFFECTIVE IS UNDERGRADUATE AND POSTGRADUATE TEACHING IN OPHTHALMOLOGY?
}

\author{
G. N. SHUTTLEWORTH and G. W. MARSH \\ Bristol
}

\begin{abstract}
SUMMARY
Purpose: To gain an insight into the adequacy of ophthalmic medical education for doctors in the primary care setting.

Methods: A short forced-choice questionnaire was set to 150 randomly selected primary care practitioners in and around Bristol. Information was collected in relation to undergraduate and postgraduate ophthalmic education, ophthalmic confidence, facilities and understanding.

Results: One hundred and thirty-three primary care doctors replied to the questionnaire of whom $35 \%$ were fundholders and $47 \%$ in training practices. Only $22 \%$ of all respondents felt their undergraduate ophthalmic medical education to be adequate. However, $83 \%$ of the 86 primary care doctors who had attended postgraduate update courses in ophthalmology felt these to be adequate. Despite the availability of an ophthalmoscope and distance vision chart, only $56 \%$ felt confident with the ophthalmoscope and only $61 \%$ reported that their distance chart was set up in accord with manufacturer's instructions. Seventy-one per cent of respondents reported having access to dilating agents but only $61 \%$ felt confident using them. Understanding of two key ophthalmic terms was also poor. Despite the general satisfaction, attendance of postgraduate update courses did not appear to alter facilities, confidence or understanding.

Conclusions: It is apparent that most primary care doctors view their undergraduate ophthalmic medical education as inadequate and this is reflected in their confidence and understanding. Postgraduate courses, although more favourably received, do not appear to alter these findings. We strongly suggest, therefore, that general ophthalmic education is aimed at teaching examination techniques and ophthalmological principles suitable for primary care practice.
\end{abstract}

From: Bristol Eye Hospital, Lower Maudlin Street. Bristol BS1 2LX, UK.

Correspondence to: G. N. Shuttleworth, Bristol Eye Hospital, Lower Maudlin Street, Bristol BS1 2LX, UK..
Eye problems make up a significant proportion of primary care consultations $(2-3 \%)^{1-5}$ and nearly one-fifth of accident and emergency consultations. ${ }^{6}$ Each year $4 \%$ of patients report to their general practitioner (GP) with eye disorders. ${ }^{7}$ These facts are not always reflected in the time allocated for undergraduate clinical teaching of ophthalmology, which averages 2 weeks or about $1.5 \%$ of the clinical curriculum. Surveys of a variety of medical practitioners have shown that it is generally accepted that ophthalmology should be taught as a separate subject at medical school. ${ }^{6,8}$ In addition, GPs and ophthalmologists agree that ideally the duration of such a course should be 5 weeks. 6.8

In the light of the limited undergraduate exposure to ophthalmology that GPs are likely to have received, it is perhaps not surprising that inadequacies relating to diagnosis and management of eye disease, ${ }^{9-11}$ referral accuracy ${ }^{12.13}$ and confidence in dealing with eye disease ${ }^{2.11}$ have regularly been highlighted.

The present study was performed to gain an insight into the adequacy of both undergraduate and postgraduate ophthalmic training as perceived by doctors in the primary care setting.

\section{METHODS}

In the autumn of 1995 a simple questionnaire (Fig. 1) was sent to 150 randomly selected GPs in and around Bristol. Two months later, a second identical questionnaire was sent to those GPs who had failed to reply.

A simple, forced-choice questionnaire, requiring only 20 responses was designed in order to encourage response, and for ease of tabulation and statistical analysis. Information was sought relating to the perceived adequacy of both undergraduate and postgraduate ophthalmic education, to primary care ophthalmic facilities, and confidence with 
Directions: - Please answer all questions.

- Please circle the most appropriate responses.

[1[ Please indicate:

Your age in years

Whether you are: IN GROUP PRACTICE ${ }_{[1]}$ SINGLE HANDED SI] $_{[2]}$

Are you a G.P. fundholder: $\mathbf{Y E S}_{[1]} \mathbf{N O}_{[2]}$

Are you a training practice: $\mathbf{Y E S}_{[1]} \mathbf{N O}_{[2]}$

[2] Do you have ready access to an ophthalmoscope?

$$
\text { YES }_{[1]} \text { NO }_{[2]} \quad \text { UNCERTAIN }_{[3]}
$$

[3] How confident do you feel when using an ophthalmoscope?
CONFIDENT $_{[1]}$
UNEASY $_{[2]}$
VERY UNEASY $Y_{[3]}$

[4] Have you ever used your ophthalmoscope to examine the anterior segment?

$$
\text { YES }_{[1]} \quad \mathbf{N O}_{[2]} \quad \text { UNCERTAIN }_{[3]}
$$

[5] Do you know what the [Marcus Gunn] swinging flashlight test is used for?

$$
\text { YES }_{[1]} \quad \text { NO }_{[2]} \quad \text { UNCERTAIN }_{[3]}
$$

[6] Do you have ready access to a distance vision chart - Snellen or equivalent chart?

$$
\text { YES }_{[1]} \quad \text { NO }_{[2]} \quad \text { UNCERTAIN }_{[3]}
$$

[7] If you have access to a distance vision chart, is it set up precisely in accord with the manufacturer's instructions?

$$
\text { YES }_{[1]} \quad \text { NO }_{[2]} \quad \text { UNCERTAIN }_{[3]}
$$

[8] Do you have ready access to any form of fluorescein dye?

$$
\text { YES }_{[1]} \text { NO }_{[2]} \quad \text { UNCERTAIN }_{[3]}
$$

[9] Do you possess a blue light for use with fluorescein?

$$
\text { YES }_{[1]} \quad \text { NO }_{[2]} \quad \text { UNCERTAIN }_{[3]}
$$

[10] Do you have ready access to dilating drops?

$$
\text { YES }_{[1]} \quad \text { NO }_{[2]} \quad \text { UNCERTAIN }_{[3]}
$$

Please indicate the type you use: tropicamide / phenylephrine / cyclopentolate / atropine / homatropine / uncertain other

[11] Do you feel confident using dilating drops?

$$
\mathbf{Y E S}_{[1]} \quad \mathbf{N O}_{[2]}
$$

[12] How likely do you feel you are to precipitate acute glaucoma using dilating drops?

$$
\text { LIKELY }_{[1]} \quad \text { NOT UNCOMMONLY }{ }_{[2]} \text { UNLIKELY }_{[3]}
$$

[13] Do you understand the significance of the term afferent pupillary defect?
$\mathbf{Y E S}_{[1]}$
NO ${ }_{[2]}$
UNCERTAIN $_{[3]}$

[14] Do you feel that your ophthalmic undergraduate medical education was:

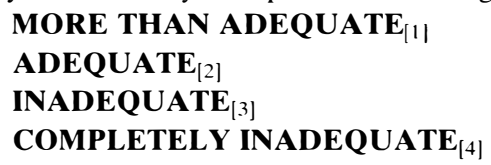

[15] Have you ever attended an 'update' course in ophthalmology?

$$
\mathbf{Y E S}_{[1]} \quad \mathbf{N O}_{[2]}
$$

[16] If you have ever attended an 'update' course in ophthalmology - did you find it:

$$
\begin{aligned}
& \text { MORE THAN ADEQUATE } \\
& \text { ADEQUATE }_{[2]} \\
& \text { INADEQUATE }_{[3]} \\
& \text { COMPLETELY INADEQUATE }
\end{aligned}
$$

Many thanks for your time.

Fig. 1. Survey questionnaire. 
Table I. Age and breakdown of practice types

\begin{tabular}{|c|c|c|c|c|c|}
\hline & \multirow{2}{*}{$\begin{array}{l}\text { Mean } \\
\text { age } \\
\text { (years) }\end{array}$} & \multicolumn{2}{|c|}{ Training practice } & \multicolumn{2}{|c|}{ Fundholding practice } \\
\hline & & Yes & No & Yes & No \\
\hline All repondents & 43.6 & $\begin{array}{c}47 \% \\
(61 / 129)\end{array}$ & $\begin{array}{c}53 \% \\
(68 / 129)\end{array}$ & $\begin{array}{c}35 \% \\
(46 / 131)\end{array}$ & $\begin{array}{c}65 \% \\
(85 / 131)\end{array}$ \\
\hline Training practices & 43.1 & NA & NA & $\begin{array}{c}51 \% \\
(31.61)\end{array}$ & $\begin{array}{c}49 \% \\
(30 / 61)\end{array}$ \\
\hline Non-training practices & 44.3 & NA & NA & $\begin{array}{l}21 \% \\
(14 / 67)\end{array}$ & $\begin{array}{c}79 \% \\
(53.67)\end{array}$ \\
\hline Fundholders & 43.5 & $\begin{array}{c}69 \% \\
(31 / 45)\end{array}$ & $\begin{array}{c}31 \% \\
(14 / 45)\end{array}$ & NA & NA \\
\hline Non-fundholders & 43.3 & $\begin{array}{c}36 \% \\
(30 / 83)\end{array}$ & $\begin{array}{c}64 \% \\
(53 / 83)\end{array}$ & NA & NA \\
\hline 41 years and under & 36.8 & $\begin{array}{c}47 \% \\
(30 / 64)\end{array}$ & $\begin{array}{c}53 \% \\
(34 / 64)\end{array}$ & $\begin{array}{c}33 \% \\
(22 / 66)\end{array}$ & $\begin{array}{c}67 \% \\
(44 / 66)\end{array}$ \\
\hline 42 years and older & 50.5 & $\begin{array}{l}48 \% \\
(31 / 65)\end{array}$ & $\begin{array}{c}52 \% \\
(34 / 65)\end{array}$ & $\begin{array}{c}37 \% \\
(24 / 65)\end{array}$ & $\begin{array}{c}63 \% \\
(41 / 65)\end{array}$ \\
\hline Update course attended & 45.1 & $\begin{array}{c}49 \% \\
(41 / 83)\end{array}$ & $\begin{array}{c}51 \% \\
(42 / 83)\end{array}$ & $\begin{array}{c}38 \% \\
(32 / 85)\end{array}$ & $\begin{array}{c}62 \% \\
(53 / 85)\end{array}$ \\
\hline No update course & 40.5 & $\begin{array}{c}42 \% \\
(19 / 45)\end{array}$ & $\begin{array}{c}58 \% \\
(26 / 45)\end{array}$ & $\begin{array}{c}29 \% \\
(13 / 45)\end{array}$ & $\begin{array}{c}71 \% \\
(32 / 45)\end{array}$ \\
\hline
\end{tabular}

ophthalmic examination. In addition, the medical school from which respondents graduated was identified from the 1995 Medical Register.

The data collected were analysed using Microsoft Access and Excel software. Difference in proportion tests and chi-squared tests were used to assess the statistical significance of the findings.

\section{RESULTS}

One hundred and thirty-three (89\%) questionnaires were returned, one of which was not completed. Incomplete and spoiled (e.g. two boxes ticked) responses were excluded from subsequent analysis.

The mean age of the respondents was 43.6 years, and the median age (41 years) was used to divide the respondents into two groups providing data relating to the time since completion of undergraduate training. Ninety-six per cent $(119 / 124)$ were in group practice, $35 \%(46 / 131)$ were fundholders and $47 \%(61 / 129)$ worked in training practices (Table I).
Training practice and fundholding were statistically associated $\left(p<0.001, \chi^{2}\right.$ Yates $)$, with $51 \%(31 / 61)$ of training practices being fundholding compared with $21 \%(14 / 67)$ of non-training practices.

The place of undergraduate medical education was identified in $89 \%(118 / 132)$ of cases, with $31 \%$ (37/ 118) having trained in Bristol, 27\% (32/118) having trained in London medical schools and $42 \%$ (49/118) having trained elsewhere.

Only 22\% (29/130) of respondents felt that their undergraduate ophthalmic medical education was adequate, and none reported it to be more than adequate (Table II). Of the remainder, 53\% (69/130) felt it to be inadequate and $25 \%(32 / 130)$ completely inadequate. Sixty-six per cent $(86 / 131)$ of respondents had attended an update course in ophthalmology. Of these, $74 \%(64 / 86)$ reported the course to be adequate and $9 \%(8 / 86)$ more than adequate. However, $16 \%(14 / 86), 1$ in 6 , felt these courses to be inadequate. Respondents aged 42 years or more

Table II. Perception of undergraduate and postgraduate ophthalmic education

\begin{tabular}{|c|c|c|c|c|c|c|c|}
\hline & \multicolumn{3}{|c|}{ Undergraduate } & \multicolumn{4}{|c|}{ Postgraduate - Update } \\
\hline & Adequate & Inadequate & $\begin{array}{l}\text { Completely } \\
\text { inadequate }\end{array}$ & $\begin{array}{c}\text { More than } \\
\text { adequate }\end{array}$ & Adequate & Inadequate & $\begin{array}{l}\text { Completely } \\
\text { inadequate }\end{array}$ \\
\hline \multirow[t]{2}{*}{ All respondents } & $22 \%$ & $53 \%$ & $25 \%$ & $9 \%$ & $74 \%$ & $15 \%$ & $1 \%$ \\
\hline & $(29 / 130)$ & $(69 / 130)$ & $(32 / 130)$ & $(8 / 86)$ & $(64 / 86)$ & $(13 / 86)$ & $(1 / 86)$ \\
\hline \multirow[t]{2}{*}{ Training practices } & $22 \%$ & $50 \%$ & $28 \%$ & $7 \%$ & $83 \%$ & $10 \%$ & - \\
\hline & $(13 / 60)$ & $(30 / 60)$ & $(17 / 60)$ & $(3 / 41)$ & $(34 / 41)$ & $(4 / 41)$ & \\
\hline & $(15 / 67)$ & $(38 / 67)$ & $(14 / 67)$ & $(5 / 42)$ & $(27 / 42)$ & $(9 / 42)$ & $(1 / 42)$ \\
\hline \multirow[t]{2}{*}{41 years or less } & $22 \%$ & $55 \%$ & $22 \%$ & $5 \%$ & $78 \%$ & $16 \%$ & - \\
\hline & $(15 / 67)$ & $(37 / 67)$ & $(15 / 67)$ & $(2 / 37)$ & $(29 / 37)$ & $(6 / 37)$ & \\
\hline \multirow[t]{2}{*}{42 years or more } & $22 \%$ & $51 \%$ & $27 \%$ & $12 \%$ & $71 \%$ & $14 \%$ & $2 \%$ \\
\hline & $(14 / 63)$ & $(32 / 63)$ & $(17 / 63)$ & $(6 / 49)$ & $(35 / 49)$ & $(7 / 49)$ & $(1 / 49)$ \\
\hline \multirow[t]{2}{*}{ Update course attended } & $22 \%$ & $47 \%$ & $31 \%$ & $9 \%$ & $74 \%$ & $15 \%$ & $1 \%$ \\
\hline & $(19 / 85)$ & $(40 / 85)$ & $(26 / 85)$ & $(8 / 86)$ & $(64 / 86)$ & $(13 / 86)$ & $(1 / 86)$ \\
\hline No update course & $\begin{array}{c}22 \% \\
(10 / 45)\end{array}$ & $\begin{array}{c}64 \% \\
(29 / 45)\end{array}$ & $\begin{array}{c}13 \% \\
(6 / 45)\end{array}$ & - & - & - & - \\
\hline
\end{tabular}


Table III. Availability of 'tools' for ophthalmic examination

\begin{tabular}{|c|c|c|c|c|c|c|c|c|c|}
\hline & \multicolumn{3}{|c|}{ Fluorescein dye } & \multicolumn{3}{|c|}{ Blue light } & \multicolumn{3}{|c|}{ Dilating drops } \\
\hline & Yes & No & Uncertain & Yes & No & Uncertain & Yes & No & Uncertain \\
\hline All respondents & $\begin{array}{c}89 \% \\
(116 / 131)\end{array}$ & $\begin{array}{c}11 \% \\
(14 / 131)\end{array}$ & $\begin{array}{c}1 \% \\
(1 / 131)\end{array}$ & $\begin{array}{c}53 \% \\
(70 / 131)\end{array}$ & $\begin{array}{c}44 \% \\
(58 / 131)\end{array}$ & $\begin{array}{c}2 \% \\
(3 / 131)\end{array}$ & $\begin{array}{c}71 \% \\
(94 / 132)\end{array}$ & $\begin{array}{c}24 \% \\
(32 / 132)\end{array}$ & $\begin{array}{c}5 \% \\
(6 / 132)\end{array}$ \\
\hline Training practices & $\begin{array}{c}95 \% \\
(58 / 61)\end{array}$ & $\begin{array}{c}5 \% \\
(3 / 61)\end{array}$ & - & $\begin{array}{c}60 \% \\
(36 / 60)\end{array}$ & $\begin{array}{c}37 \% \\
(22 / 60)\end{array}$ & $\begin{array}{c}3 \% \\
(2 / 60)\end{array}$ & $\begin{array}{c}90 \% \\
(55 / 61)\end{array}$ & $\begin{array}{c}10 \% \\
(6 / 61)\end{array}$ & - \\
\hline Non-training practices & $\begin{array}{c}82 \% \\
(55 / 67)\end{array}$ & $\begin{array}{c}16 \% \\
(11 / 67)\end{array}$ & $\begin{array}{c}1 \% \\
(1 / 67)\end{array}$ & $\begin{array}{c}46 \% \\
(31 / 68)\end{array}$ & $\begin{array}{c}53 \% \\
(36 / 68)\end{array}$ & $\begin{array}{l}1 \% \\
(1 / 68)\end{array}$ & $\begin{array}{c}53 \% \\
(36 / 68)\end{array}$ & $\begin{array}{c}38 \% \\
(26 / 68)\end{array}$ & $\begin{array}{c}9 \% \\
(6 / 68)\end{array}$ \\
\hline 41 years or less & $\begin{array}{c}91 \% \\
(60 / 66)\end{array}$ & $\begin{array}{c}9 \% \\
(6 / 66)\end{array}$ & - & $\begin{array}{c}61 \% \\
(41 / 67)\end{array}$ & $\begin{array}{c}36 \% \\
(24 / 67)\end{array}$ & $\begin{array}{c}3 \% \\
(2 / 67)\end{array}$ & $\begin{array}{c}75 \% \\
(50 / 67)\end{array}$ & $\begin{array}{c}22 \% \\
(15 / 67)\end{array}$ & $\begin{array}{c}3 \% \\
(2 / 67)\end{array}$ \\
\hline 42 years or more & $\begin{array}{c}96 \% \\
(56 / 65)\end{array}$ & $\begin{array}{l}12 \% \\
(8 / 65)\end{array}$ & $\begin{array}{c}2 \% \\
(1 / 65)\end{array}$ & $\begin{array}{c}45 \% \\
(29 / 64)\end{array}$ & $\begin{array}{c}53 \% \\
(34 / 64)\end{array}$ & $\begin{array}{l}2 \% \\
(1 / 64)\end{array}$ & $\begin{array}{c}68 \% \\
(44 / 65)\end{array}$ & $\begin{array}{c}26 \% \\
(17 / 65)\end{array}$ & $\begin{array}{c}6 \% \\
(4 / 65)\end{array}$ \\
\hline Update course & $\begin{array}{c}88 \% \\
(76 / 86)\end{array}$ & $\begin{array}{l}10 \% \\
(9 / 86)\end{array}$ & $\begin{array}{c}1 \% \\
(1 / 86)\end{array}$ & $\begin{array}{c}52 \% \\
(44 / 85)\end{array}$ & $\begin{array}{c}46 \% \\
(39 / 85)\end{array}$ & $\begin{array}{c}2 \% \\
(2 / 85)\end{array}$ & $\begin{array}{c}76 \% \\
(65 / 86)\end{array}$ & $\begin{array}{c}20 \% \\
(17 / 86)\end{array}$ & $\begin{array}{c}5 \% \\
(4 / 86)\end{array}$ \\
\hline No update course & $\begin{array}{c}89 \% \\
(39 / 44)\end{array}$ & $\begin{array}{l}11 \% \\
(5 / 44)\end{array}$ & - & $\begin{array}{c}58 \% \\
(26 / 45)\end{array}$ & $\begin{array}{c}40 \% \\
(18 / 45)\end{array}$ & $\begin{array}{c}2 \% \\
(1 / 45)\end{array}$ & $\begin{array}{c}62 \% \\
(28 / 45)\end{array}$ & $\begin{array}{c}33 \% \\
(15 / 45)\end{array}$ & $\begin{array}{c}4 \% \\
(2 / 45)\end{array}$ \\
\hline
\end{tabular}

were more likely to have attended an update course than their younger colleagues $\left(p<0.02, \chi^{2}\right.$ Yates $)$.

Ninety-nine per cent $(131 / 132)$ of respondents had an ophthalmoscope and $98 \%(130 / 132)$ a distance vision chart. However, only $61 \%$ (79/130) of respondents reported that the set-up of the distance chart was in accordance with the manufacturer's instructions, whilst $24 \%(31 / 130)$ reported that it was set up incorrectly. Seventy-one per cent (94/132) had access to dilating drops and $89 \%(116 / 131)$ to fluorescein dye (Table III). However, only $60 \%$ (69/115) of those with fluorescein also had a blue light with which to facilitate examination. Of those with access to dilating drops, $82 \%(83 / 95)$ had access to tropicamide, $11 \%(15 / 95)$ had access to cyclopentolate and 5\% (5/95) both. One respondent had access to homatropine and another to atropine only.

Those in training practices were more likely to have access to both dilating drops $\left(p<0.0001, \chi^{2}\right.$ Yates $)$ and fluorescein dye $\left(p<0.05, \chi^{2}\right.$ Yates $)$ than were colleagues in non-training practices.

Only $56 \%(71 / 126)$ of respondents felt confident using the ophthalmoscope, leaving 43\% (55/126) feeling uneasy or very uneasy (Table IV). Those over

Table IV. Reported confidence with ophthalmic examination

\begin{tabular}{lccccc}
\hline & \multicolumn{2}{c}{ Ophthalmoscopy } & & \multicolumn{2}{c}{ Dilating drops } \\
\cline { 2 - 3 } \cline { 5 - 6 } & Yes & No & & Yes & No \\
\hline All respondents & $56 \%$ & $43 \%$ & & $61 \%$ & $39 \%$ \\
& $(71 / 126)$ & $(55 / 126)$ & & $(79 / 129)$ & $(50 / 129)$ \\
Training practices & $66 \%$ & $34 \%$ & $75 \%$ & $25 \%$ \\
& $(38 / 58)$ & $(20 / 58)$ & & $(46 / 61)$ & $(15 / 61)$ \\
Non-training practices & $46 \%$ & $54 \%$ & & $46 \%$ & $54 \%$ \\
& $(30 / 65)$ & $(35 / 65)$ & & $(30 / 65)$ & $(35 / 65)$ \\
41 years or less & $47 \%$ & $53 \%$ & $62 \%$ & $38 \%$ \\
& $(30 / 64)$ & $(34 / 64)$ & & $(41 / 66)$ & $(25 / 66)$ \\
42 years or more & $66 \%$ & $34 \%$ & $60 \%$ & $40 \%$ \\
& $(41 / 62)$ & $(21 / 62)$ & & $(38 / 63)$ & $(25 / 63)$ \\
Update course attended & $61 \%$ & $39 \%$ & $65 \%$ & $35 \%$ \\
& $(50 / 82)$ & $(32 / 82)$ & & $(54 / 83)$ & $(29 / 83)$ \\
No update course & $49 \%$ & $51 \%$ & $56 \%$ & $44 \%$ \\
& $(21 / 43)$ & $(22 / 43)$ & $(25 / 45)$ & $(20 / 45)$ \\
\hline
\end{tabular}

41 years of age were more likely to be confident when compared with younger colleagues $(p<0.05$, $\chi^{2}$ Yates $)$, as were those in training practices compared with non-training practices $\left(p<0.05, \chi^{2}\right.$ Yates $)$.

Sixty-one per cent (79/129) of respondents felt confident using dilating drops and again those in training practices were more likely to feel confident $\left(p<0.002, \chi^{2}\right.$ Yates $)$. Only $2 \%(2 / 127)$ of respondents thought that precipitation of acute angle closure glaucoma was likely, with a further $14 \%(18 / 127)$ considering it not uncommon (Table V). The majority $(84 \%, 107 / 127)$, however, thought the complication very uncommon despite one reporting personal experience of such an event. Although those who lacked confidence reported a higher perceived risk of precipitation of acute angle closure this did not reach statistical significance $(p=0.07$, $\chi^{2}$ Yates).

Only 34\% (44/130) of respondents understood the meaning of an afferent pupillary defect whilst even fewer $(10 \%, 13 / 130)$ knew of the (Marcus Gunn) swinging flashlight test (Table V). Only 8\% (10/130) understood both and 64\% (83/130) understood neither. Although respondents who had attended an ophthalmology update course reported understanding the meaning of an afferent pupillary defect more commonly, the difference did not reach statistical significance $\left(p=0.09, \chi^{2}\right)$.

\section{DISCUSSION}

The high response to our questionnaire compared with other studies ${ }^{6,8,11}$ probably reflects both the simple questionnaire design and the local nature of the sample population, and means that respondents are likely to be representative. Despite the limitations of such a questionnaire, in particular its brevity combined with its broad scope, the results highlight a number of important issues for ophthalmic education.

It is a matter of concern that only $22 \%$ of respondents felt that their ophthalmic undergraduate 
Table V. Familiarity with ophthalmic terms and complications

\begin{tabular}{|c|c|c|c|c|c|c|c|c|c|}
\hline & \multicolumn{3}{|c|}{$\begin{array}{l}\text { Use of Marcus Gunn/ } \\
\text { swinging flashlight test }\end{array}$} & \multicolumn{3}{|c|}{$\begin{array}{c}\text { The term afferent pupillary } \\
\text { defect }\end{array}$} & \multicolumn{3}{|c|}{$\begin{array}{l}\text { The risk of precipitation of } \\
\text { AACG }\end{array}$} \\
\hline & Yes & No & Uncertain & Yes & No & Uncertain & Likely & Not uncommonly & Unlikely \\
\hline All respondents & $\begin{array}{c}10 \% \\
(13 / 131)\end{array}$ & $\begin{array}{c}81 \% \\
(106 / 131)\end{array}$ & $\begin{array}{c}9 \% \\
(12 / 131)\end{array}$ & $\begin{array}{c}34 \% \\
(44 / 131)\end{array}$ & $\begin{array}{c}40 \% \\
(52 / 131)\end{array}$ & $\begin{array}{c}27 \% \\
(35 / 131)\end{array}$ & $\begin{array}{c}2 \% \\
(2 / 127)\end{array}$ & $\begin{array}{c}14 \% \\
(18 / 127)\end{array}$ & $\begin{array}{c}84 \% \\
(107 / 127)\end{array}$ \\
\hline Training practices & $\begin{array}{c}8 \% \\
(5 / 61)\end{array}$ & $\begin{array}{c}85 \% \\
(52 / 61)\end{array}$ & $\begin{array}{c}7 \% \\
(4 / 61)\end{array}$ & $\begin{array}{c}37 \% \\
(22 / 60)\end{array}$ & $\begin{array}{c}40 \% \\
(24 / 60)\end{array}$ & $\begin{array}{c}23 \% \\
(14 / 60)\end{array}$ & $\begin{array}{c}2 \% \\
(1 / 59)\end{array}$ & $\begin{array}{c}8 \% \\
(5 / 59)\end{array}$ & $\begin{array}{c}90 \% \\
(53 / 59)\end{array}$ \\
\hline Non-training practices & $\begin{array}{l}10 \% \\
(7 / 67)\end{array}$ & $\begin{array}{c}79 \% \\
(53 / 67)\end{array}$ & $\begin{array}{l}10 \% \\
(7 / 67)\end{array}$ & $\begin{array}{l}31 \% \\
(21 / 68)\end{array}$ & $\begin{array}{c}41 \% \\
(28 / 68)\end{array}$ & $\begin{array}{c}28 \% \\
(19 / 68)\end{array}$ & $\begin{array}{l}2 \% \\
(1 / 65)\end{array}$ & $\begin{array}{l}20 \% \\
(13 / 65)\end{array}$ & $\begin{array}{l}78 \% \\
(51 / 65)\end{array}$ \\
\hline 41 years or less & $\begin{array}{l}13 \% \\
(9 / 67)\end{array}$ & $\begin{array}{c}75 \% \\
(50 / 67)\end{array}$ & $\begin{array}{l}12 \% \\
(8 / 67)\end{array}$ & $\begin{array}{l}37 \% \\
(25 / 67)\end{array}$ & $\begin{array}{l}33 \% \\
(22 / 67)\end{array}$ & $\begin{array}{l}30 \% \\
(20 / 67)\end{array}$ & - & $\begin{array}{l}11 \% \\
(7 / 65)\end{array}$ & $\begin{array}{c}89 \% \\
(58 / 65)\end{array}$ \\
\hline 42 years or more & $\begin{array}{c}6 \% \\
(4 / 64)\end{array}$ & $\begin{array}{l}88 \% \\
(56 / 64)\end{array}$ & $\begin{array}{c}6 \% \\
(4 / 64)\end{array}$ & $\begin{array}{l}30 \% \\
(19 / 64)\end{array}$ & $\begin{array}{c}47 \% \\
(30 / 64)\end{array}$ & $\begin{array}{l}23 \% \\
(15 / 64)\end{array}$ & $\begin{array}{c}3 \% \\
(2 / 62)\end{array}$ & $\begin{array}{l}18 \% \\
(11 / 62)\end{array}$ & $\begin{array}{l}79 \% \\
(49 / 62)\end{array}$ \\
\hline Update course attended & $\begin{array}{r}9 \% \\
(8 / 86)\end{array}$ & $\begin{array}{l}78 \% \\
(67 / 86)\end{array}$ & $\begin{array}{l}13 \% \\
(11 / 86)\end{array}$ & $\begin{array}{c}40 \% \\
(34 / 86)\end{array}$ & $\begin{array}{c}34 \% \\
(29 / 86)\end{array}$ & $\begin{array}{l}27 \% \\
(23 / 86)\end{array}$ & $\begin{array}{l}1 \% \\
(1 / 83)\end{array}$ & $\begin{array}{l}11 \% \\
(9 / 83)\end{array}$ & $\begin{array}{c}88 \% \\
(73 / 83)\end{array}$ \\
\hline No update course & $\begin{array}{l}11 \% \\
(5 / 44)\end{array}$ & $\begin{array}{c}86 \% \\
(38 / 44)\end{array}$ & $\begin{array}{c}2 \% \\
(1 / 44)\end{array}$ & $\begin{array}{c}22 \% \\
(10 / 45)\end{array}$ & $\begin{array}{c}51 \% \\
(23 / 45)\end{array}$ & $\begin{array}{c}27 \% \\
(12 / 45)\end{array}$ & $\begin{array}{c}2 \% \\
(1 / 44)\end{array}$ & $\begin{array}{l}20 \% \\
(9 / 44)\end{array}$ & $\begin{array}{c}77 \% \\
(34 / 44)\end{array}$ \\
\hline
\end{tabular}

AACG, Acute angle closure glaucoma.

education was adequate. The fact that both younger and older respondents were in agreement indicates a long-standing dissatisfaction by those in the primary care setting with traditional methods of ophthalmic teaching. This may reflect a combination of factors including course content and objectives, which are usually the responsibility of hospital staff often far removed from primary care practice; the inadequacy of timetable allocation; and the loss of focus resulting from combination with training in other specialties.

It is encouraging that $66 \%$ of respondents had attended an update course in ophthalmology and that attendance was not related to the perceived adequacy of undergraduate education $\left(p=0.07 \chi^{2}\right)$. Respondents over 41 years of age were more likely to have attended such a course compared with their younger colleagues, perhaps reflecting a perception of greater need or the number of years in practice. Satisfaction with postgraduate update courses was a great deal higher than for undergraduate education, with only $16 \%$ of respondents reporting update courses to be inadequate. This may reflect the opportunity to address problems relevant to the primary care setting, greater motivation and enthusiasm for learning amongst course participants, or the formation of enduring professional relationships with course organisers.

Access to an ophthalmoscope and a distance vision chart was almost universal amongst respondents, a finding in accord with a recent survey in south Devon. ${ }^{2}$ However, only $60 \%$ reported that the distance chart was set up in accordance with the manufacturer's instructions, drawing attention once again to the questionable reliability of visual acuity assessment in general practice,$^{14}$ and only $56 \%$ of respondents felt confident using an ophthalmoscope. Older GPs were more likely to report feeling confident, due possibly to greater experience or differing expectation. Similarly, respondents from training practices were more likely to feel confident than colleagues in non-training practices, perhaps reflecting their enthuasism for teaching. Those in training practices were, however, no more likely to have attended update courses in ophthalmology nor were they on average older and more experienced than those from non-training practices. The lack of confidence using the ophthalmoscope reflects poorly upon the ophthalmic teaching community, as proficiency with this instrument must surely be regarded as a basic requirement for every primary care practitioner.

Although nearly $90 \%$ reported having access to fluorescein dye, only $60 \%$ of these had a blue light, the use of which will enhance considerably the assessment of the corneal and conjunctival surfaces. Only $71 \%$ of respondents reported having dilating agents and $19 \%$ of these did not feel confident in their use. As such, it is doubtful whether the figures accurately reflect the use of such agents. The majority of those with dilating drops had either tropicamide or cyclopentolate or both. These drops differ only slightly and both may be safely used for diagnostic dilation; however, tropicamide is usually preferred for its short duration of action. It is of some concern that one respondent reported access only to atropine drops, which are not recommended for routine pupillary dilatation due to their prolonged duration of action (i.e. several days).

Overall, only $61 \%$ of respondents reported feeling confident with dilating drops, a figure similar to that for confidence with the ophthalmoscope. Those from training practices were once again more likely to feel confident than non-training practice colleagues. Concerns regarding the precipitation of acute angle closure glaucoma seem unlikely to be related to this lack of confidence, as $84 \%$ of respondents correctly perceive the risk to be very small. ${ }^{15.16}$ It is more likely, therefore, that the lack of confidence with the 
ophthalmoscope underlines the similar lack of confidence with dilating drops. Although dilating a patient's pupils prolongs the consultation, examination through a dilated pupil will engender greater confidence in ophthalmoscopy and must be encouraged.

It is interesting to note that respondents from training practices appeared to be better equipped with respect to fluorescein and dilating agents and felt more confident with ophthalmoscopy and pupillary dilation than those in non-training practices despite similar update course attendance and experience. The precise reasons for this remain unanswered but must inevitably reflect enthusiasm and understanding.

It was thought that understanding the meaning of an afferent pupillary defect and the purpose of the (Marcus Gunn) swinging flashlight test should be familiar to most doctors as these are important in ophthalmology, neurology and general medicine. However, both were infrequently understood by respondents. Ophthalmic update course attendance appeared to have little effect and highlights the dichotomy regarding the perceived adequacy of update courses and their educative effectiveness.

In conclusion, the most striking result of this survey was that so few GPs felt their undergraduate ophthalmic education to be adequate. This is reflected in a lack of confidence using the ophthalmoscope and dilating agents despite the ready availability of such basic ophthalmic equipment. Although a large proportion of those attending continuing medical education courses thought them to be adequate, it is of concern that such attendance did not appear to significantly alter ophthalmic confidence or understanding.

At the present time ophthalmology constitutes a compulsory component of all United Kingdom medical courses with an average duration of exposure in the order of 2 weeks (unpublished telephone survey: see Appendix). Medical students are, however, often taught in conjunction with other 'minor' specialist subjects and the resulting distractions may leave the student without a thorough understanding of basic eye care. The function of undergraduate medical education is usually regarded as preparation for subsequent postgraduate training and not competency for immediate practice. ${ }^{17}$ It is clear, however, that the limited number and size of ophthalmic specialist units is such that only a privileged few will be able to gain additional ophthalmic experience during their vocational training programmes. We therefore recommend that the principal objective of ophthalmic undergraduate education should be to prepare students to a standard adequate for primary care practice. Future undergraduate courses should provide a basic understanding of ophthalmic princi- ples and conditions, ensure competent ophthalmic examination skills (especially ophthalmoscopy) and the use of dilating agents and fluorescein dye. Until undergraduate education addresses these issues, we suggest that update courses should reiterate these objectives and emphasise basic skills.

\section{APPENDIX}

Results of unpublished telephone survey (Feb 1996) of United Kingdom medical schools

A telephone survey of all United Kingdom medical schools revealed that ophthalmology is currently included in all clinical curricula, most commonly in the fourth year. In 9 institutions, ophthalmology was taught in combination with, on average, two or three other subjects. Assuming equal priorities, the average duration of exposure to ophthalmology was a little under 2 working weeks. One medical school reported that ophthalmology is taught in all three clinical years and two others offered optional 1 or 2 week attachments in addition to their compulsory course.

Key words: Medical education, Eye diseases, Primary care, Questionnaires, Great Britain.

\section{REFERENCES}

1. Dart JKG. Eye disease at a community health centre. BMJ 1986;293:1477-80.

2. Featherstone PI, James C, Hall MS, Williams A. General practitioners' confidence in diagnosing and managing eye conditions: a survey in South Devon. $\mathrm{Br}$ J Gen Pract 1992;42:21-4.

3. Shields T, Sloane PD. A comparison of eye problems in primary care and ophthalmology practices. Fam Med 1991;23:544-6.

4. McDonnell PJ. How do general practitioners manage eye disease in the community? $\mathrm{Br} \mathrm{J}$ Ophthalmol 1988;72:733-6.

5. Royal College of General Practitioners, Office of Population Censuses and Surveys and Department of Health and Social Security. Morbidity statistics from general practice 1981-1982. Series MBS no. 1. London: HMSO, 1986.

6. Vernon SA. Eye care and the medical student: where should emphasis be placed in undergraduate ophthalmology? J R Soc Med 1988;81:335-7.

7. Sheldrick JH, Wilson AD, Vernon SA, Sheldrick CM. Management of ophthalmic disease in general practice. Br J Gen Pract 1993;43:459-62.

8. Stark D, Beinssen A, Morrey C. Ophthalmology in the undergraduate curriculum. Aust NZ J Ophthalmol 1992;20:297-303.

9. Claoué CMP, Stevenson KE. Incidence of inappropriate treatment of herpes simplex keratitis with topical steroids. BMJ 1986;292:1450-1.

10. Lavin MJ, Rose GE. Use of steroid eye drops in general practice. BMJ 1986;292:1448-50.

11. Wilson A. The red eye: a general practice survey. J R Coll Gen Pract 1987;37:62-4. 
12. Harrison RJ, Wild JM, Hobley AJ. Referral patterns to an ophthalmic outpatient clinic by general practitioners and ophthalmic opticians and the role of these professionals in screening for ocular disease. BMJ 1988;297:1162-7.

13. Brittain GPH, Austin DJ, Kelly SP. A prospective survey to determine sources and diagnostic accuracy of glaucoma referrals. Health Trends 1988;20:43-4.

14. Pandit JC. Testing acuity of vision in general practice: reaching recommended standard. BMJ 1994;309:1408.
15. Congdon N, Wang F, Tielsch JM. Issues in the epidemiology and population-based screening of primary angle-closure glaucoma. Surv Ophthalmol 1992; 36:411-23.

16. Patel KH, Javitt JC, Tielsch JM, Street DA, Katz J, Quigley HA, Sommer A. Incidence of acute angleclosure glaucoma after pharmacological mydriasis. Am J Ophthalmol 1995;120:709-17.

17. Fraser RC. Undergraduate medical education: present state and future needs. BMJ 1991;303:41-3. 